\title{
THE ROLE OF SOCIAL ENTREPRENEURSHIP AND SOCIAL INNOVATION IN REGIONAL DEVELOPMENT
}

Svetlana POLOVKO, Latvia University of Life Sciences and Technologies, Lielā iela 2, Jelgava, LV-3001, Latvia, svetlana.polovko@inbox.lv

In world economic development, the importance of innovations, including social innovations, is acquiring an increasingly important role. But it is necessary to take different groups of factors into account in the state's innovation policy, is due to the fact that they can both contribute to and hinder innovative development. Social entrepreneurship is an effective tool for solving social problems and contributes to leveling the shortcomings of state management of a market economy. It acts as a connecting bridge between the public and private sectors, while working closely with both. The aim of research is to determine the stimulating and inhibiting factors for the development of social innovations. This research identifies factors and effect of social entrepreneurship and social innovation in regional development. The study uses monographic method, methods of analysis and synthesis, method of scientific induction and scientific deduction. In scope of the research, the author have clarified role of social entrepreneurship and social innovation in regional development, and create classification of financing resources for social innovation.

Keywords: social innovation, social entrepreneurship, regional development.

\section{INTRODUCTION}

The innovative development of regions can be influenced by different groups of factors, for example, both technological and social in nature. The need to take these and other groups of factors into account in the state's innovation policy, is due to the fact that they can both contribute to and hinder innovative development. For instance, values and behavioral attitudes can have a positive effect on the attitude of the population towards new technologies and entrepreneurship, which can also influence their economic behavior (Lehtola, Stahle, 2014). The opposite is also true: the results of innovative development can influence the formation of attitudes towards innovative activity among the population.

In world economic development, the importance of innovations, including social innovations, is acquiring an increasingly important role, despite significant differences in the level of development of different countries. A characteristic feature of the gradual transition to an innovative model on a global scale, is the formation of two approaches to the implementation of innovations - technocratic and socially oriented. The process of development and humanization of modern society has led to the fact that from a wide variety of types of innovations, a separate type of them stood out - social innovations related to the social sphere and associated with personal interests, but also with the interests of the state.

The aim of research is to determine the stimulating and inhibiting factors for the development of social innovations. In this article we examine, that social innovations are viewed as a society's "response" to emerging problems (growth in unemployment, poverty; environmental change, etc.), as their new solutions, expressed in the emergence of services aimed at improving the level and quality of life of the population, for the development of new forms of interaction between the state, business and society, etc., for example, reducing the level of poverty while increasing the level of social protection of the population and, as a result, relieving social tension.

Perhaps this is why "social innovation" is associated with social entrepreneurship and public-private partnerships. Note that the need for cooperation between participants in the development and implementation of social innovation projects is determined by different circumstances, among which, for example, the heterogeneity of non-governmental organizations, the difference in their incentives and barriers to the provision of social services. (Mumford, 2002) This is meaningfully expressed in the fact that some organizations can reduce costs on the basis of economies of scale, while others, on the contrary, are low-profit, but at the same time have social motivation for the development and implementation of social innovation projects. By uniting various participants in this process, it becomes possible to take into account each other's strengths, not only economic, but also social motives come to the fore.

Social entrepreneurship is an effective tool for solving social problems and contributes to leveling the shortcomings of state management of a market economy. It acts as a connecting bridge between the public and private sectors, while working closely with both. Social entrepreneurship is flexible enough and is able to quickly respond to changes in market conditions, including under the influence of crisis processes. (Lawrence et al., 2010) Thus, according to the European Commission, the impetus for the development of social entrepreneurship in Europe was given by the global economic crisis

Copyright () 2021 The Authors. Published by Vytautas Magnus University. This is an open-access article distributed under the terms of the Creative Commons Attribution License (CC BY 4.0), which permits unrestricted use, distribution, and reproduction in any medium, provided the original author and source are credited. 
of 2009, which caused an increase in interest in systems in which a large number of diverse and equal participants are involved, including social business. Social entrepreneurship has the qualities of all sectors of the economy, namely, it uses market instruments in the implementation of its projects, smoothes out social tensions by solving certain social problems, and helps to eliminate market failures in the production of public goods (European Commission, 2013).

\section{RESEARCH METHODS}

The study uses monographic method, methods of analysis and synthesis, method of scientific induction and scientific deduction.

\section{RESEARCH RESULTS AND DISCUSSION}

During the development of innovation theories, many researchers have confirmed, that there are direct correlation between the innovative development of territories and their socio-economic success: economic growth, increasing competiveness, increasing business activity and public welfare (Mensch, 1972; Freeman, 1987; Cooke, 1997; Asheim et al., 1995; Lim, 2004). Consequently, the creation of an effective innovation system that would promote the innovative development of the theritory is currently one of the priority tasks in territorial and regional development. There are now more than twenty theories of innovative development of territories in economics, but the focus of current research is to study social innovation from regional perspective.

Over the last twenty years, there has been growing interest in researching territorial innovation system at the national or regional level. The concept of modern innovation systems is based on the classical theory of innovation, which is shown in Fig.1.

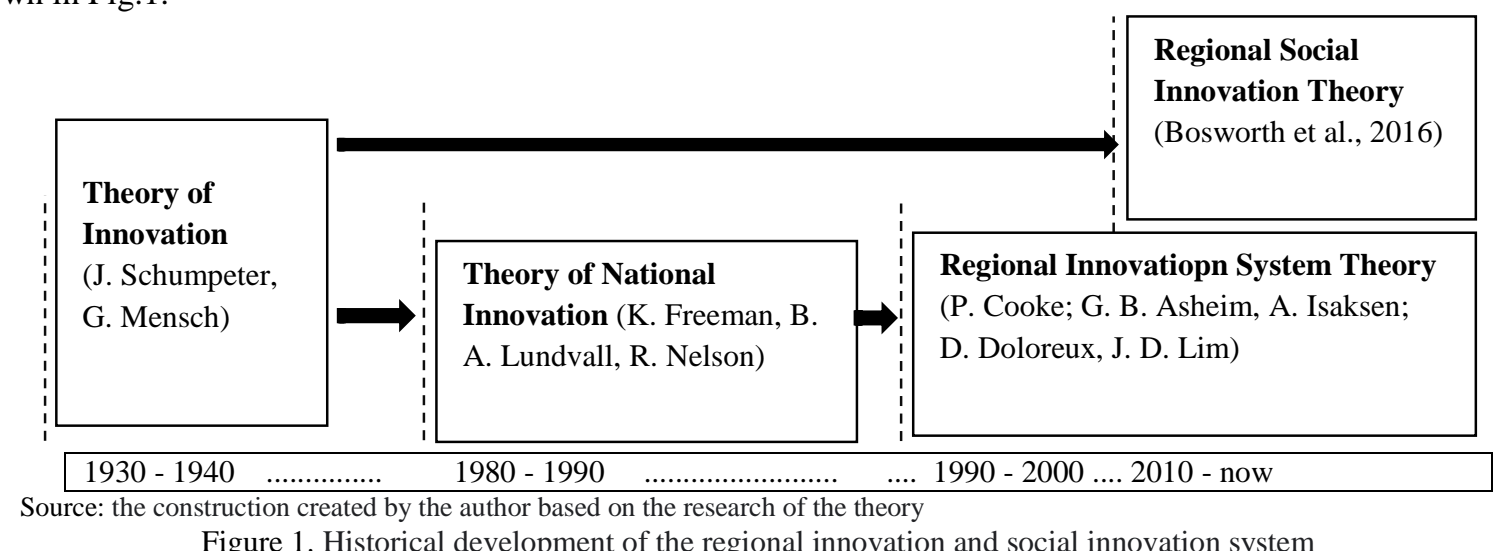

Figure 1. Historical development of the regional innovation and social innovation system

Within the framework of the research, the author has summarized the main findings of innovation theory, in order to show the formation of innovation and later also social innovation in the regional context (Table 1).

Table 1. Summary of innovation theory findings in a regional context

\begin{tabular}{|l|l|}
\hline Scientists & \\
\hline Schumpeter, 1934 & $\begin{array}{l}\text { - emphasized the importance of economic innovation in relation to production; } \\
\text { - separated the concepts of "invention" and "innovation"; } \\
\text { - emphasized the role of the entrepreneur-innovation in the dynamic changes in the economy. }\end{array}$ \\
\hline Mensch, 1972 & $\begin{array}{l}\text { - developed the investment S-model; } \\
\text { - demonstrated that the development of innovation contributes to economic growth. }\end{array}$ \\
\hline Freeman, 1987 & $\begin{array}{l}\text { - examined the intitutional role of the national innovation system, stressing that the dissemination of innovation } \\
\text { technologies requires systematic support in the public and private sectors. }\end{array}$ \\
\hline Lundvall, 1992 & $\begin{array}{l}\text { - researched that the ability of companies to implement innovative development depends on the level of } \\
\text { development and organization of the country's scientific and technical progress. }\end{array}$ \\
\hline Nelson, 1993 & $\begin{array}{l}\text { - demonstrated that the development of scientific and technical progress is hampered by centralized national } \\
\text { planning and management; } \\
\text { - in his view, a large number of possible independent developments contribute to the diversity of research and } \\
\text { the creation of innovation. }\end{array}$ \\
\hline Cooke, 1997 & $\begin{array}{l}\text { - emphasized the importance of the social and economic process of knowledge/innovation creation in fostering } \\
\text { the innovative development of regions. }\end{array}$ \\
\hline Asheim et al., 1995 & - identified the role of the region as an innovation system in sustainable economic development. \\
\hline Doloreux, 2002 & $\begin{array}{l}\text { - defines the regional innovation system as a set of different organizations and entities that promote innovative } \\
\text { development. }\end{array}$ \\
\hline Gertler, 2004 & - emphasizes the role of innovation-oriented companies in regional development. \\
\hline Lim, 2004 & $\begin{array}{l}\text { - establishes a regional innovation system as a system that stimulates the innovative development of } \\
\text { organizations located in the territory of the region. }\end{array}$ \\
\hline Bosworth et al., 2016 & $\begin{array}{l}\text { - based on the findings of Schumpeter's theory of innovation, defines the importance and application of social } \\
\text { innovation in regional development. }\end{array}$ \\
\hline
\end{tabular}


As shown on Table 1, research on social innovation in regional context has been developing in last decade, and, by author's view, is related to the increase of popularity of social innovation and social entrepreneurship in different countries.

Regarding the issues of identifying the role of social entrepreneurship, it should be noted that there are significant difficulties in quantifying it in the economy and society: measuring the scale of social entrepreneurship, international comparison, assessing the contribution to national economies, regional economies and economic unions. The main reason for this is that in the legislation of many countries there is no legally enshrined definition of social entrepreneurship and it can be implemented in various organizational and legal forms (Phills et al., 2008).

The development of social entrepreneurship and the implementation of social innovation is one of the priority tasks of the socio-economic development of the European Union. The main legislative and financial instruments that indicate the importance of social innovation in the EU can be identified:

1) First of all, the "Europe 2020" strategy and its two flagship directions "Innovation Union" and "European policy against poverty". Both areas include large-scale activities and financing the development of cooperation between authorities, non-profit organizations, business and social entrepreneurs in one or more countries (Europe 2020, 2013).

2) The Social Business Initiative - a number of financial and legislative initiatives aimed at the development of social entrepreneurship, investment in human capital, research, development and dissemination of social innovation and the development of microfinance. Financial support includes the possibility of financing from the European Regional Development Fund ( $€ 183$ billion in 2014-2020) and the European Social Fund ( $€ 80$ billion, 2014-2020).

3) Social Investment Package, a set of measures for the development and use of social investments by the EU member states for social protection (European Comission, 2015).

It can also be noted that in the social sphere, unlike, for example, the spheres of transport, health care or construction, the main role in the production and dissemination of social innovations belongs to civil society organizations - social enterprises, as locally rooted organizations, conductors of current citizens' initiatives. However, it is not yet very clear what conditions and characteristics of social enterprises determine the participation of an organization in the production and dissemination of social innovation.

The current situation with innovations can be compared with social marketing, the social foundations of which, according to Philip Kotler (Kotler, 1991), are primarily the satisfaction of human needs. From the author's point of view, the impulse from society is one of the necessary elements of social innovation.

It is also important to pose the problem of assessing the effectiveness of social innovations: it is necessary to somehow measure their effectiveness, to what extent they solve people's problems (Westley, 2010). From the author's point of view, in our country, there is no significant correlation between the cost of innovation and the contribution to GDP. It is known that in the case of technological innovations, high risks are covered by high wages and profits, which cannot be the case with social enterprises, and this must be taken into account by researchers of this issue. It would also be more efficient to look for social innovations in individual sectors and compare them with each other than to select broadly across all social enterprises at once.

Having studied all possible sources of financing for social innovation, the author proposed a classification of these sources according to several criteria. The purpose of this classification is to systematize all elements into one structure (Fig. 2).

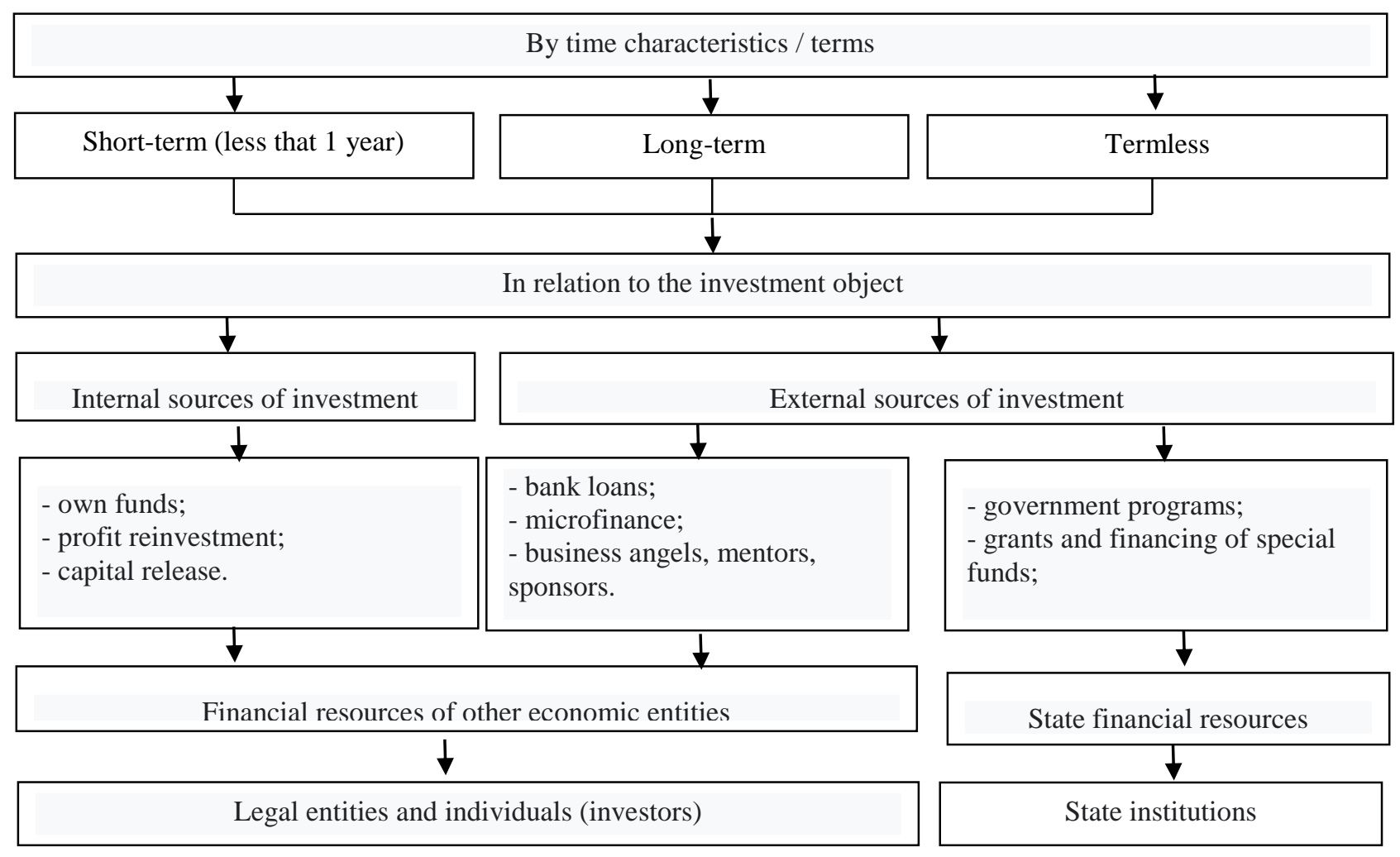

Figure 2. The author's classification of sources of financing for social innovation 
To determine the stimulating and inhibiting factors for the development of social innovations, two areas of support for the development of social innovations can be distinguished:

- creation of non-governmental specialized organizations that support social entrepreneurship and coordinate the availability of investment in social innovation;

- government participation, within the framework of which active work is underway on strategic planning, networking, financing in the field of social entrepreneurship.

We also note three key reasons that hinder the rapid development of social entrepreneurship and the implementation of social innovations:

- misunderstanding of the very essence of social entrepreneurship, due to which even existing entrepreneurs do not identify themselves as social;

- insufficiently complete regulation of the financing of social entrepreneurship, difficulties in filing an application for financing social innovation;

- lack of resources, primarily financial.

To level these problems, it is necessary to solve the following tasks:

- creation of favorable conditions for the development of social entrepreneurship in the region;

- active involvement of social entrepreneurs in the provision of state and municipal social services;

- increasing the efficiency of the system of state support for social entrepreneurship;

- attracting additional financing to the social sphere from medium and large businesses;

- improving the business climate and overcoming administrative barriers;

- creating a positive image of social entrepreneurs in the region;

- popularization of social entrepreneurship among the population;

- development of priority spheres of activity (education, healthcare, production) in order to eliminate the existing imbalances.

\section{CONCLUSION}

For the active development of social entrepreneurship and the active implementation of social innovations, a scientific study of its concept is required, including the formation of a conceptual apparatus, the allocation of classification features, an analysis of problems and prospects of functioning. This direction is quite promising for the world scientific community.

As a result of the research, it has been established, that the development of social innovation in the regional aspect has been updated only in the last decade, and requires more in-depth theoretical research.

In the course of research, it has been established that the main stimulating factors for social innovation in the regional aspect are the arrangement of the institutional environment in the public and private sectors, the promotion of investment access and effective strategic planning. In turn, the factors hindering social entrepreneurship and social innovation are the lack of understanding of the nature of social innovation, lack of resources (especially financial resources), as well as various bureaucratic obstacles to the development of social entrepreneurship.

The search for effective forms of financing and methods for regulating the development of social innovation, involves modeling effective means of efficient financial impact of stakeholders in the creation of specialized organizations, whose activities can contribute to the more active development of social entrepreneurship and the use of various possibilities for solving financial problems of its functioning.

Within the framework of this article, it was possible to identify the reasons that hinder the development of social entrepreneurship, as well as to determine the prospects for the development of this economic phenomenon.

Acknowledgements. The author participates in ES29 project Nr.8.2.2.0/18/A/014 - "LLU development of academic staff", which cofunded the research project that this article is based on.

\section{REFERENCES}

1. Asheim, B., Isaksen, A. 2002. "Regional innovation systems: the integration of local 'sticky' and global 'ubiquitous' knowledge”. Journal of Technology Transfer, Vol. 27, pp. 77-86. https://doi.org/10.1023/A:1013100704794

2. Cooke, P., Uranga, M. G., Etxebarria, G. 1997. Regional innovation systems: Institutional and organizational dimensions. Research Policy, Vol. 26, Issues 4-5, pp. 475-491, 478. https://doi.org/10.1016/S0048-7333(97)00025-5

3. Doloreux, D. 2002. What we should know about regional systems of innovation. Technology in Society, Vol. 24, pp. $243-263$. https://doi.org/10.1016/S0160-791X(02)00007-6

4. European Commission. 2013. Guide to Social Innovation. Brussels: EU. Available at http://ec.europa.eu/regional_policy/ sources/docgener/presenta/social_innovation/social_innovation_2013.pdf (accesed on 11/09/2021)

5. European Comission. 2013. Europe 2020 Strategy, Brussels. Available at https://ec.europa.eu/eu2020/pdf /COMPLET\% 20EN\%20BARROSO\%20\%20\%20007\%20-\%20Europe\%202020\%20-\%20EN\%20version.pdf (accesed on 11/09/2021)

6. European Comission. 2019. Towards a sustainable Europe by 2030. Available at https://ec.europa.eu/info/publications/towardssustainable-europe-2030_en (accesed on 11/09/2021) 
7. European Comission. 2015. The social business initiative Ref. Ares(2015)5946494 - 18/12/2015. Available at https://ec.europa.eu/ growth/content/social-business-initiative-sbi-follow-cooperation-between-social-economy-enterprises-and_en (accesed on 11/09/2021)

8. Freeman, C. 1987. Technology and Economic Performance: Lessons from Japan. London: FrancesPrinter Publishers, P. 32.

9. Kotler, P. 1991. Principles of marketing. Englewood Cliffs, N.J. :Prentice Hall.

10. Lawrence, T. B., Dover, G., Gallagher, B. 2013. Managing social innovation. In M. Dodgson, D. M. Gann, \& N. Phillips (Eds.), The Oxford handbook of innovation management. Oxford, UK: Oxford University Press. https://doi.org/10.1093/oxfordhb/9780199694945.013.032

11. Lehtola, V. V., Stahle, P. 2014. Societal innovation at the interface of the state and civil society. Innovation: The European Journal of Social Sciences, Vol.27(1), pp. 152-174. https://doi.org/10.1080/13511610.2014.863995

12. Lim J. D. 2004. Regional Innovation System for Regional Development. Journal of School of Business, Vol. 76.

13. Lundvall, B. A. 1992. National systems of innovation: towards a theory of innovation and interactive learning. London, Pinter Publisching.

14. Mensch, G. 1972. Basisinnovationen und Verbesserungsinnovationen. / G. Mensch // Zeitschrift furBetriebswirtschaft, No. 42, pp. 291-297.

15. Mumford, M. D. 2002. Social innovation: Ten cases from Benjamin Franklin. Creativity Research Journal, Vol. 14(2), pp. 253266. https://doi.org/10.1207/S15326934CRJ1402_11

16. Nelson, R. R. 1993. National Innovation Systems: A Comparative Analysis, Oxford: Oxford University Press.

17. Phills, J. A., Deigmeir, K., Miller, D. T. 2008. Rediscovering social innovation. Stanford Social Innovation Review, Vol. 6(4), pp. 34-43.

18. Schumpeter, J. 1987. Theorie der wirtschaftlichen Entwicklung: e. Unters, uber Untemehmergewinn,Kapital, Kredit, Zins u.d. Konjunkturzyklus / von Joseph Schumpeter. - 7. Aufl., unverand. Nachdr.d. 1934 erschienenen 4. Aufl. - Berlin: Duncker und Humblot

19. Westley, F., Antadze, N. 2010. Strategies for scaling social innovation for greater impact. The Innovation Journal: The Public Sector Innovation Journal, Vol. 15(2), pp. 2-18. 